\title{
画像演算を用いた固有振動モードトラッキングのアルゴリズム*
}

\author{
榎 本 裕 久*1, 坂 本茂*2
}

\section{Tracking Algorithm of Natural Vibration Modes Using Image Operation}

\author{
Hirohisa ENOMOTO and Shigeru SAKAMOTO*3 \\ *3 Mechanical Engineering Research Laboratory, Hitachi, Ltd. \\ 832-2 Horiguchi, Hitachinaka-shi, Ibaraki, 312-0034 Japan
}

\begin{abstract}
A new algorithm using image operation was developed for identifying and tracking a natural vibration mode that is one of the most important factors in structural design. It enables the automatic survey of parameters in the vibration design of structures even when mode switching (crossing) occurs. Mode switching is the change of order in which natural vibration modes appear. The developed algorithm performs the following tasks. First, the absolute value of each component of a vector corresponding to a natural vibration mode is represented as a gray-scale image by a post processor. Each of the gray-scale images is then binarized. The numbers of groups consisting of pixels with the same color are counted in each binary image, and the numbers are used for distinguishing the natural vibration mode to be tracked from the other modes. A structural optimization system was developed. It consists of the software routine using the developed algorithm, a commercial optimization software, pre and post processors, and a calculation solver. The effectiveness of the algorithm using a cantilever plate whose natural vibration mode appearance order varies in changing the design parameters was tested and verified. A new reinforcing rib was then added to the cantilever plate that requires re-meshing. The effectiveness of the algorithm was also tested and verified on the modified plate.
\end{abstract}

Key Words: Modal Analysis, Computer Aided Design, Finite Element Method, Natural Frequency, Natural Vibration Mode, Mode-Tracking, Image Operation, Structural Optimization

\section{1. 緒 言}

振動設計では，仕様を満足する形状を見出すため， 構造物の寸法, 部材の位置, 個数など多くの設計変数 をパラメータとし, 形状変更を繰り返しながら構造を 最適化していくこの過程において, 避共振設計, つ まり加振力によって振動が大きくなる固有振動モード の固有振動数を加振振動数から遠ざけることは, 最も 重要な課題の一つである. 振動設計では, 計算ソルバ に有限要素法が多く用いられる: また，それらを自動 実行して最適な設計パラメータを見つける最適化ソフ トウェアも普及している. しかし, 構造物には一般に 多くの固有振動モードが存在するが, 設計変数の変更, つまり形状変更の過程において, それらの出現する順 番の入替（モードスイッチング）が生じる場合がある.

* 原稿受付 2006 年 3 月 31 日.

*1 (株) 日立製作所機械研究所( 312-0034 ひたちなか市堀口 832-2).

*2 正員, (株) 日立製作所機械研究所.

E-mail : shigeru.sakamoto.xx@ hitachi.com
これが，振動設計において，設計変数のパラメータサ 一ベイを自動化するときの障害となる.

振動設計では, 設計変数の変更前後で生じるモード スイッチングに対応するため, 固有振動モードを判別 して追跡 (トラッキング) する必要がある. 固有振動 モードの判別には, 固有振動モ一ド同士の正規化され た内積であるModal Assurance Criterion（MAC）(1)を用い る方法や，質量マトリックスに左右から固有ベクトル をかけた值を用いる，（Cross）Orthogonality Check (CORC) (1) と呼ばれる方法がある.これらの方法を 用いたモードスイッチングに対応する研究もいくつか

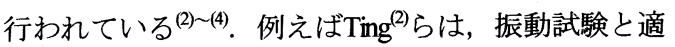
合する有限要素モデル作成のため, パラメータ探索の 際にモードスイッチングが生じても, MACの值で固 有振動モードを追跡することにより自動計算を可能と

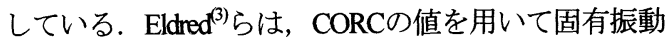

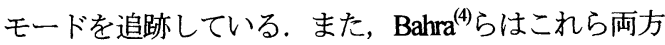
を用い，比較を行っている.この他，反復計算ごとに 前ステップで用いた固有振動数及び固有振動モードの 
変化を計算し，これらの変化からモードスイッチング が起こる位置を判断する方法も提案されている( ${ }^{(3)}$. MAC やCORCを用いる固有振動モードトラッキングは, いくつかの市販の最適化ソフトウェアでも採用されて いる. しかし，これらの方法を実際の構造物の振動設 計で生じるモードスイッチング問題を解決する手段と して採り入れるのは, 必ずしも有効とは限らない. こ の点については, 次節で詳しく説明する.

上記以外の方法として，馬(5) ${ }^{(9)}$, 複数の固有値に 重み付けしたものを足し合わせることで，モードスイ ッチングによって急激に固有值が変わることを防ぎ, 解を収束させる手法を報告している．しかし，モード スイッチングが生じても最適化計算を続行させる点で は有効であるものの，特定の固有振動モードに着目す るものではないため, 実際の構造物の設計で必要とな る避共振設計等のモードスイッチング問題の解決に用 いるのには適当な手段とは言えない，

そこで本論文では，実際の構造物の振動設計で生じ るモードスイッチングに有効で，しかも汎用性がある 新しい固有振動モードトラッキングのアルゴリズムを 提案する. 本アルゴリズムを実行する固有振動モード トラッキングのソフトウェアルーティンを開発し, 計 算例を通して有效性を示す.

\section{2. 振動設計における問題と開発課題}

モードスイッチングに対応するために固有振動モー ドを判別する代表的な方法として，以下の二つがある. まずMACを用いた方法は，式（1）に示すように， $k$ 回目の形状変更後の论の固有ベクトル $\varphi_{i}{ }^{k}$ と, $k+1$ 回目 の形状変更後の $j$ 次の固有ベクトル $\varphi_{j}{ }^{k+1}$ の正規化され た内積をとり，その値により，固有振動モードを判別 する方法である(2)(4)

$$
\operatorname{MAC}\left(\varphi_{i}^{k}, \varphi_{j}^{k+1}\right)=\frac{\left|\left(\varphi_{i}^{k}\right)^{T}\left(\varphi_{j}^{k+1}\right)\right|^{2}}{\left(\left(\varphi_{i}^{k}\right)^{T}\left(\varphi_{i}^{k}\right)\right)\left(\left(\varphi_{j}^{k+1}\right)^{T}\left(\varphi_{j}^{k+1}\right)\right)}
$$

つまり，固有振動モードを表すべクトルの幾何学的 な直交性を表す内積の值によって判別している．また CORCを用いた方法は, 式（2）に示すように $k+1$ 回目 の形状変更後の質量マトリックス $\boldsymbol{M}^{k+1}$ の左右から $k$ 回 目の形状変更後の论の固有ベクトル $\varphi_{i}{ }_{i}$ と, $k+1$ 回目 の形状変更後の $j$ 次の固有べクトル $\varphi_{j}^{k+1}$ をかけ, この 值により固有振動モードを判別する方法である ${ }^{(3)(4)}$. この方法では, 幾何学的直交性ではなくモードの直交 性により判別している.

$$
\operatorname{CORC}\left(\varphi_{i}^{k}, \varphi_{j}^{k+1}\right)=\left(\varphi_{i}^{k}\right)^{T} \boldsymbol{M}^{k+1}\left(\varphi_{j}^{k+1}\right)
$$

しかし，図1に例を示すように，いずれの方法も実 際の構造物の設計で生じる新たな部材の着脱など, 形 状に関する設計変数の大幅な変更を行うと, 計算メッ シュの再分割が必要となる. そのため, 同じ位置でも 節点番号が変わり, 固有ベクトルの内積をとることで は，固有振動モードの判別ができなくなる．これに対 し，予め追跡する固有振動モードを識別するのに必要 な参照点を指定しておき，これらの参照点だけを用い て固有振動モードを追跡する方法も提案されている( ${ }^{(0)}$. しかし, 大幅に形状が変更されることで, 固有振動モ ードが変化する可能性もある. 極端な場合を考えれば, 参照点として指定した点がモードの節となる可能性も あり，そのような場合には追跡が困難になると予想さ れる．また，上記のように新たな部材を着脱するよう な大幅な形状変更に対し, 汎用的な手法になり得ると はいい難い. 従って, 予め定めた参照点を用いて固有 振動モードを判別するこの方法は, 実際の構造物の設 計に用いるのに，必ずしも有効であるとはいい難い.

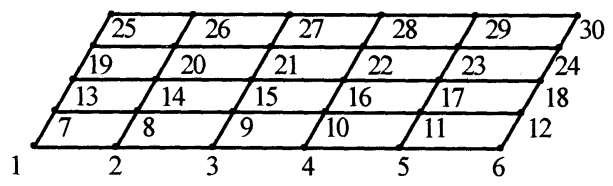

(a) Node number of initial mesh

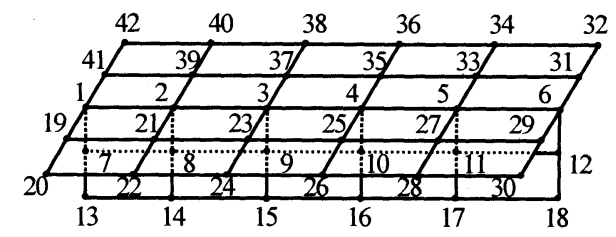

(b) Node number of modified mesh after shape change

Fig. 1 Example of shape change that requires re-meshing

そこで，ここでは従来の方法で用いている数值的な 演算ではなく, 計算結果を表示するポストプロセッサ が出力する画像に演算を施すことにより, 固有振動モ ードを追跡する方法を考案した. 計算結果をポストプ ロセッサで表示することは，ほとんどの計算ソルバが 採用している.これらの画像はデジタル化され，ピク セル (画素) ごとの演算が可能である.これにより， 固有振動モードをパターンとして認識することが可能 となるので, 上記のような節点番号の入替が起きても 固有振動モードの判別が可能であり, 汎用性のある手 法となる. 


\section{3. 画像演算による固有振動モドトラ将グ 機能の開発}

3・1 アルゴリスム提案する画像演算による固有 振動モードトラッキング機能を含めた振動設計の流れを 図2に示寸. 図2の太枠内が提案アルゴリズムである.

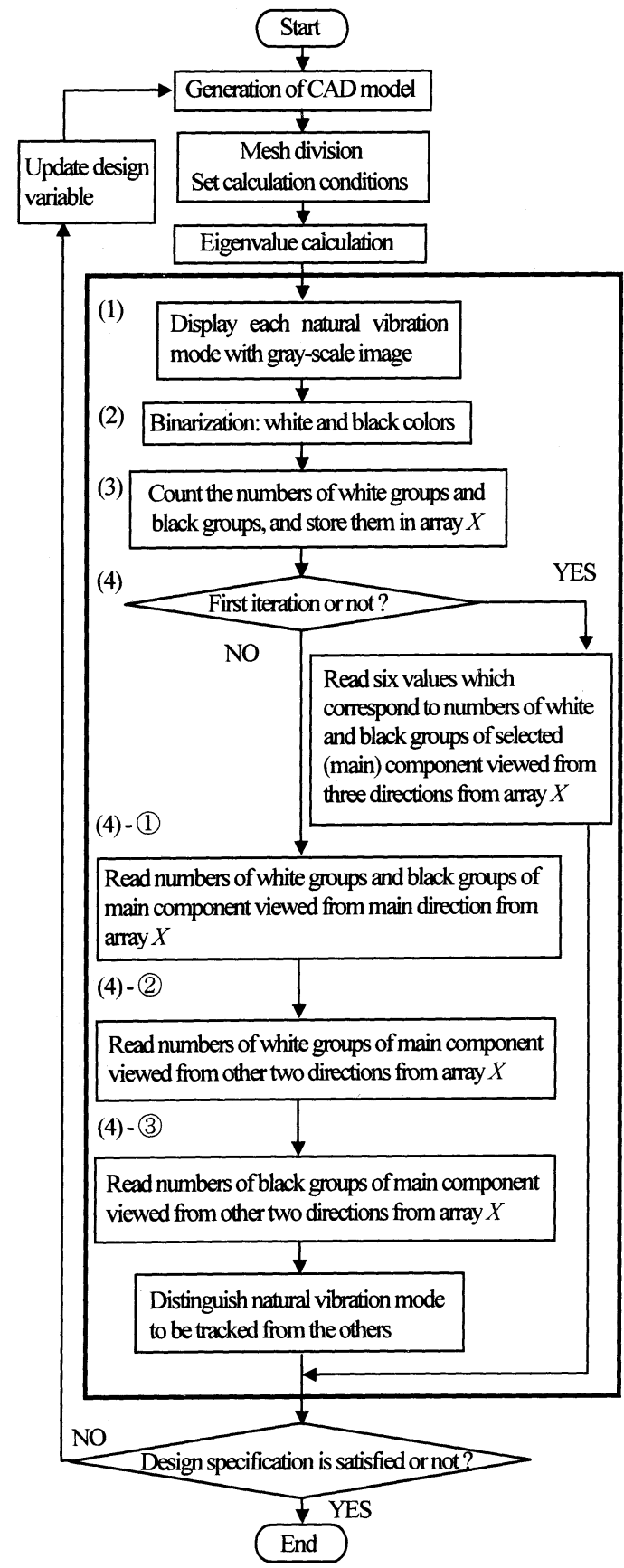

Fig. 2 Tracking algorithm of natural vibration mode
まず，CADモデルを生成し，これを計算メッシュに 分割後, 計算条件を設定する. 次に, 固有値計算を行 い，固有振動モードトラッキングを行う，その後，仕 様を満足する形状が得られれば, 計算は終了する. 満 足していなければ, 設計変数を更新し, 上記の流れを 繰り返す。

本論文で提案する固有振動モードトラッキング機能 の構成を以下に述べる.

(1) 固有振動モードベクトルの各成分の絶対值を色 の濃淡で，段階的に表示する濃淡図作成部

（2）色の濃淡の度合いに閾値を設けて，濃淡図を白 と黒に色分け寸る2值化部

(3) 2值画像において連続した同一色のピクセルで構 成される領域を一つの集合と数え, その集合の 数を数えるパターン情報抽出部

（4）上で述べた集合の数によって, 追跡する固有振 動モードを, 形状変更後の固有振動モードから 判別する固有振動モード判別部

以下に, アルゴリズムに従って固有振動モードを判 別する機能の詳細を説明する.

（1）濃淡図作成部濃淡図作成部では，ポス トプロセッサを用いて, 図3に示すように, 固有振動 モードを変形図ではなく, 濃淡図として表す。まず, 固有振動モードベクトルの各成分について，それぞれ の絶対值を算出する. 次に, それらの最大値と最小値 を求め, 最大值には白, 最小値には黒の色を割り当て, それ以外の值には, 大きさに応じて濃淡を段階的に変 えた色を与え，濃淡図を $x, y, z$ 成分ごとに作成する. これを，計算した全ての固有振動モードに対して行う.

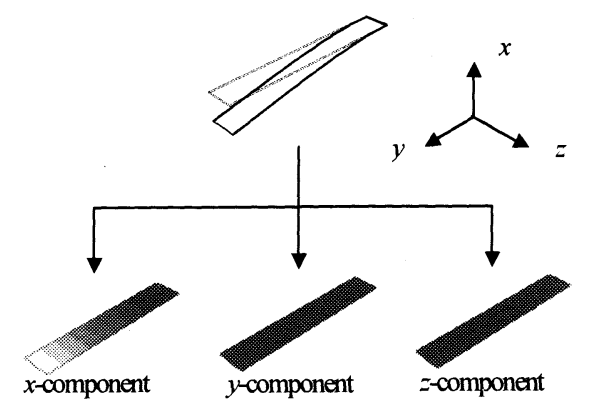

Fig. 3 Representing amplitude in each component of natural vibration mode by using gray-scale image

（2） 2值化部 判別を容易にするため，2值化 部では, 閾值を設け, 濃淡の度合いが閾値以上のピク セルは白, 閾値以下のピクセルは黒となるように2值 
化する.この処理を図4に示す．画像を一方向のみか ら表示させるだけでは，その特徴を必ずしも抽出する ことはできない，そこで，画像を $x, y, z$ の方向から 表示させ，2値化することとした。これを固有振動モ 一ドベクトルの $x, y, z$ 成分ごとに行い, 一つの固有 振動モードにつき合計9枚の2值画像を作成する.これ を, 計算した全ての固有振動モードに対して行う.

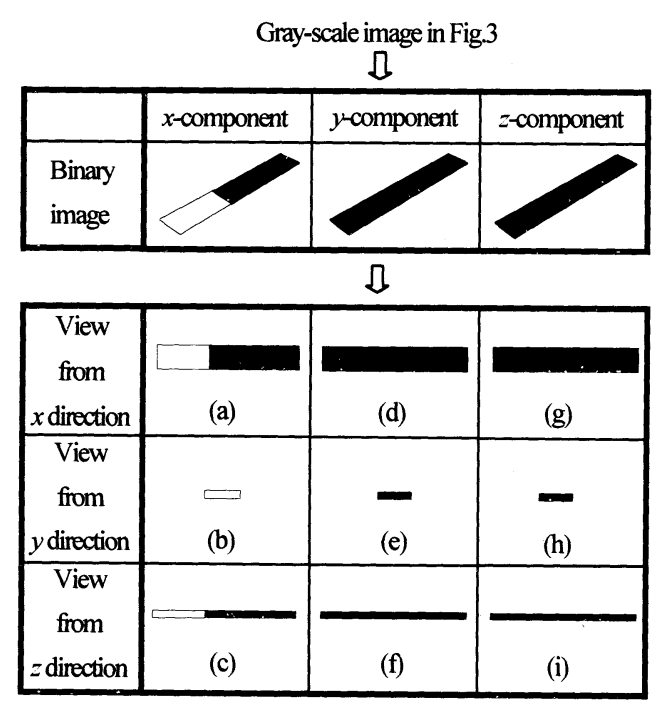

Fig. 4 Converting gray-scale image to binary image

（3）パターン情報抽出部 パターン情報抽出 部では，2值画像において白のピクセルが連続してい る領域を一つの集合と数え, その集合の数（白の集合 数： Number of white groups）を数える. さらに, 黒のピ クセルが連続している領域を一つの集合と数え, その 集合の数（黒の集合数: Number of black groups）も数え る. $j$ 次の固有振動モードの2值画像を例に，この方法 を図5に示す。

例えば，図5（a）の2值画像では, 白の集合数1, 黒 の集合数 1 と数える. これを, 画像 (a) 〜 (i) まで の9枚の2值画像全てに行う．画像（a）における白の 集合数から画像（i）に㧍ける黒の集合数に，1１8の 番号を付け, 配列Xに保存する. この集合数がパター ン情報となる.これを計算した全ての固有振動モード に対して行う.

配列Xは, 2次元配列として作成し, 配列要素は, 固 有振動モードの次数とパターン情報の番号である.こ の配列风に，形状変更毎に更新される。

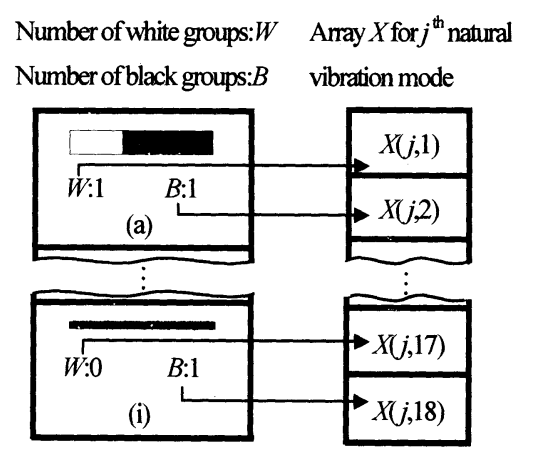

Fig 5 Method for counting and storing the number of groups consisting of pixels with the same color in binary image

（4）固有振動モード判別部 固有振動モード 判別部では，3つのステップで判別が行われる．まず, ステップ1では, 固有振動モードを表すべクトルの $x$, $y, z$ 成分のうち, 絶対值が最大值をとる成分（主成 分）を，その成分と同一の方向（主方向）から表示さ せた2值画像を，図4に示す画像（a）～(i) の中から 選択する. この画像の, 白の集合数と黒の集合数を判 別に用いる. 形状変更後の固有振動モードを表した2 値画像の白の集合数と追跡する固有振動モードを表し た2值画像の白の集合数, および, 形状変更後の固有 振動モードを表した2值画像の黒の集合数と追跡する 固有振動モードを表した2值画像の黒の集合数が一致 するものを同一の固有振動モードと判別する. 同一と 判別される固有振動モードが一つの場合は, 追跡する 固有振動モードが見つかったと判断し，判別は終了す る. 存在しない場合は, エラーとみなされ, 判別処理 は終了する.このときの計算結果は用いられない，同 一と判別される固有振動モードが複数存在する場合は, ステップ2に進む. まず，主成分を表した2值画像の うち, 主方向と異なる残りの2方向から表示させた2值 画像を選択する. これら2枚の2值画像の白の集合数を 判別に用いる. 形状変更後の固有振動モードを表した 2值画像の白の集合数と追跡する固有振動モードを表 した2值画像の白の集合数が一致するものを同一の固 有振動モードと判別する. 同一と判別される固有振動 モードが一つの場合, もしくは存在しない場合は, 先 と同様の処理を行う. 同一と判別される固有振動モー ドが複数存在する場合は, さらに, ステップ3に進む. 先の判別に使用したものと同じ2枚の2值画像の黒の集 合数を判別に用いる. 形状変更後の固有振動モードを 表した2值画像の黒の集合数と追跡する固有振動モ一 ドを表した2值画像の黒の集合数が一致するものを同 一の固有振動モードと判別する. 同一と判別される固 
有振動モードが複数存在する場合, もしくは, 存在し ない場合は, エラーとみなされ，このときの計算結果 は用いられない，白のピクセルで表示された部分は， 振幅の大きい部分であることから，黒のピクセルで表 示された部分よりもその固有振動モードの特徵を表す と考え, 先に判別に用いている. 以上が固有振動モー ド判別の概略であるが，次にこれを以下に詳述する.
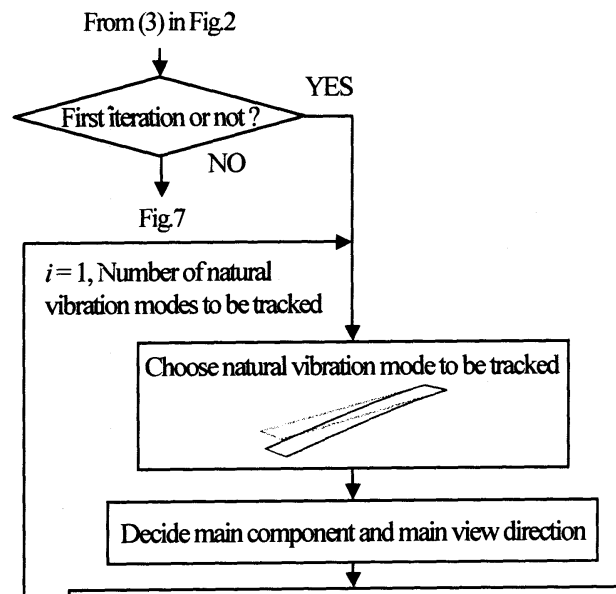

Read numbers of white groups and black groups of main component viewed from main direction from array $X$ and store them in array $R M W_{i}, R M B_{i}$ respectively

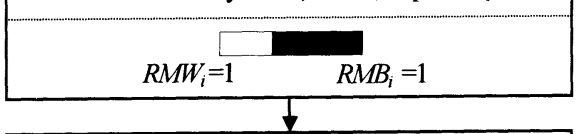

Read numbers of white groups of main component viewed from other two directions from array $X$ and store them in array $R S 1 W_{i}, R S 2 W_{i}$ respectively

\begin{tabular}{cr|}
\hline \multirow{2}{*}{$W_{i}=1$} & $R S 2 W_{i}=1$ \\
\hline
\end{tabular}

Read numbers of black groups of main component viewed from other two directions from array $X$ and store them in array $R S 1 B_{i}, R S 2 B_{i}$ respectively

$\rightleftarrows S 1 B_{i}=0$
$R S 2 B_{i}=1$

Go to last process in Fig.2

Fig. 6 Explanation of storing natural vibration mode to be tracked (the first iteration)

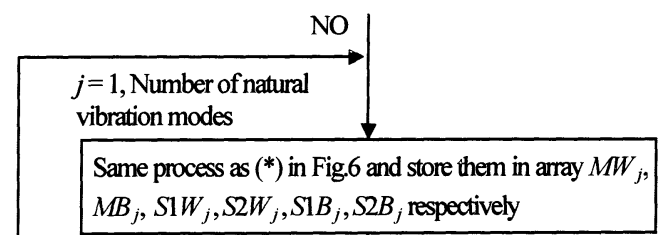

$i=1$, Number of natural

vibration modes to be tracked
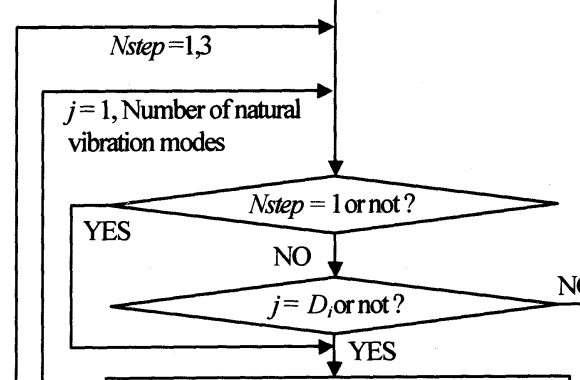

Compare $\left\{\begin{array}{l}M W_{j} \text { and } R M W_{i} \\ M B_{i} \text { and } R M B_{i}\end{array}\right\}$ in $N$ step $=1$

Compare $\left\{\begin{array}{l}S 1 W_{j} \text { and } R S 1 W_{i} \\ S 2 W_{j} \text { and } R S 2 W_{i}\end{array}\right\}$ in $N s t e p=2$

Compare $\left\{\begin{array}{l}S 1 B_{j} \text { and } R S 1 B_{i} \\ S 2 B_{j} \text { and } R S 2 B_{i}\end{array}\right\}$ in $N$ step $=3$

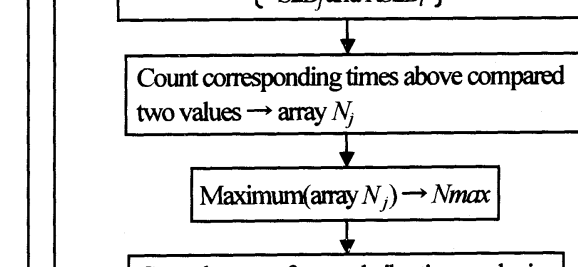

$(*)$

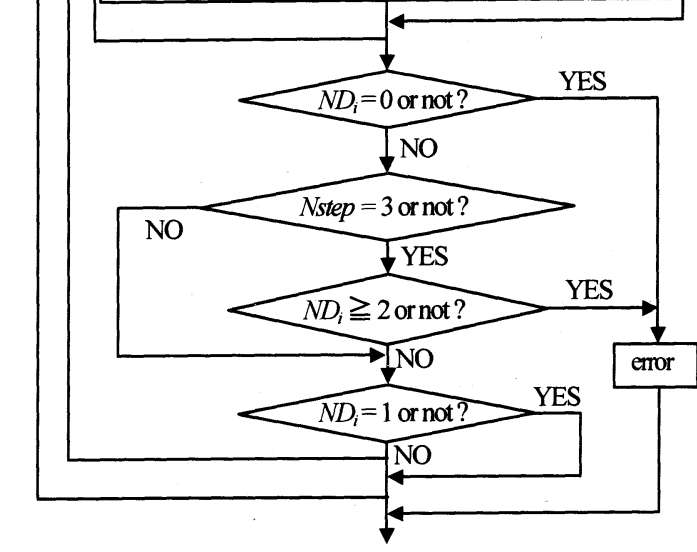

Go to last process in Fig.2

Fig. 7 Explanation for distinguishing natural vibration mode to be tracked from the other modes (after the second iteration) 
固有振動モード判別部の1回目の計算における処理 方法を図6に, 2回目以降の計算における処理方法を図 7に示す. 1回目の計算では, まず, 固有値計算の結果 から，追跡する固有振動モード $i(i=1,2, \cdots$,追跡する 固有振動モードの数）を選択する. 次に主成分と, 主 方向を設定する．設定した主成分を表す2值画像のう ち, 主方向から表示させた2值画像の白の集合数之黒 の集合数を, 配列Xからそれぞれ配列 $R M W_{i}, R M B_{i}$ へ 格納する．さらに，同椂に主成分を表す2值画像のう ち主方向と異なる残りの2方向から表示した2枚の2值 画像の白の集合数を, 配列Xからそれぞれ配列 $R S 1 W_{i}$, $R S 2 W_{i}$ 八格納する. さらに, 同じ2枚の2值画像の黒の 集合数を, 配列Xからそれぞれ配列 $R S 1 B_{i}, R S 2 B_{i}$ へ格 納する. 以後, これらの配列を参照し, 固有振動モ一 ドの判別を行う. 追跡する固有振動モードが複数存在 する場合は，これを繰り返す。

2回目以降の計算では, まず, 計算した $j$ 次の固有 振動モード $(j=1,2, \cdots$,計算した固有振動モードの 数）のパターン情報を配列Xから取り出す. 1回目の計 算と同様に，設定した主成分を表す2值画像のうち， 主方向から表示させた2值画像の白の集合数と黒の集 合数を，配列 $X$ からそれぞれ配列 $M W_{j}, M B_{j}$ 八格納寸 る. さらに，主成分を表す2值画像のうち，主方向と 異なる残りの2方向から表示した2枚の2值画像の白の 集合数を, 配列 $X$ からそれぞれ配列 $S 1 W_{j}, S 2 W_{j}$ へ格 納し, 同様に同じ2枚の2值画像の黒の集合数を, 配列 $X$ 号それぞれ配列 $S 1 B_{j} ， S 2 B_{j}$ へ格納する. これを計 算した全ての固有振動モードに対して行う.

次に，3つのステップを踏んで判別を行う．ステッ プ1では, 格納した配列 $M W_{j}, M B_{j}$ の值と参照配列 $R M W_{i}, R M B_{i}$ の值を比較する. 白, 黒の順番で比較し, 值が一致する個数を数える. 形状変更後の $j$ 次の固有 振動モードのパターン情報と追跡する固有振動モード iのパターン情報が一致する個数を配列 $N_{j}$ に格納した 後, 最大值を算出し, これをNmaxとする. 配列 $N_{j}$ の 成分の值がNmax と一致する固有振動モードの次数 $\mathrm{j}$ を 配列 $D_{i}$ に格納する. ただし, 配列 $N_{j}$ の成分の值が0の ときは格納されない.このj次の固有振動モードが, 追跡する固有振動モード $i$ と同一と判別される. また, 配列 $N D_{i}$ には同一と判別された固有振動モードの数が 格納される. 配列 $N D$,の值が2以上の場合は次のステ ップに進み, 配列 $N D_{i}$ の值が 1 の場合は, 次のステッ プに進まずこれを追跡する固有振動モードと判断し, 判別を終了する. 配列 $N D_{i}$ の值が0の場合は, エラー とみなされ，この計算結果は用いられない，

ステップ2では, ステップ1で配列 $D_{i}$ に格納された
次数 $j$ の固有振動モードを対象に, 配列 $S 1 W_{j}, S 2 W_{j}$ と参照配列 $R S 1 W_{i}, R S 2 W_{i}$ を比較し, 值が一致する個数 を数える. 以後は, ステップ1と同様の手順で処理を 行う.

最後に，ステップ3では，ステップ2で配列 $D_{i}$ に格 納された次数 $j$ の固有振動モードを対象に, 配列 $S 1 B_{j}$, $S 2 B_{j}$ と参照配列 $R S 1 B_{i} ， R S 2 B_{i}$ を比較し，值が一致する 個数を数える. 以後は, ステップ2と同様の手順で処 理を行う. 配列 $N D_{i}$ の值が2以上の場合，もしくは, 配列 $N D_{i}$ の值が0の場合は, エラーとみなされ, この ときの計算結果は, 用いられない. これら3つのステ ップを踏んで, 追跡する固有振動モードの判別を行う. 追跡する固有振動モードが複数存在する場合は, これ を繰り返す，以上，（1）から（4）までの手順を含む 図2の流れを, 終了まで繰り返す。

$3 \cdot 2$ 構造最適化システムの構成 前節で述べたア ルゴリズムを実行するソフトウェアルーティンを開発し た. これを, 最適化ソフトウェア (iSIGHT ${ }^{\mathrm{TM}}$ ) に, モデ ラ $\left(\right.$ SolidWorks $\left.{ }^{\circledR}\right)$ ，プリ・ポストプロセッサ及び計算ソ ルバ $\left(\mathrm{ANSYS}^{\circledR}\right)$ をリンクさせて構成した構造最適化シ ステムを図 8 に示寸.太枠内が開発部分であり，(1)〜 (4)の部分が前節で述べたアルゴリズムに対応する.

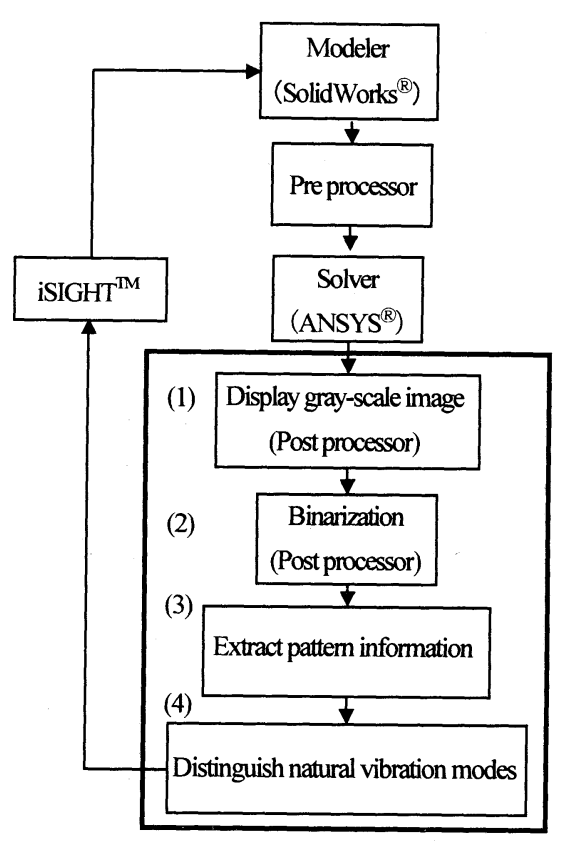

Fig. 8 Constitution of optimization system 


\section{4. 計算例}

\section{$4 \cdot 1$ 片持ち平板}

(1) 計算モテル 図9に示す一端が固定された平 板を用い，開発機能を確認する. 材質は鉄（ヤング 率: $206 \mathrm{GPa}$, 密度 : $7860 \mathrm{~kg} / \mathrm{m}^{3}$, ポアソン比 : 0.3) と し, 4面体2次要素で分割した. 板幅が $165 \mathrm{~mm}$ (初期 値）のときの固有値計算結果は, 曲げ1次モード $8.4 \mathrm{~Hz}$, 曲げ2次モード $52.4 \mathrm{~Hz}$ ，ねじりモード $99.2 \mathrm{~Hz}$ ，面内曲 げモード134.0 Hzとなる.これらのうち, ねじりモー ドと面内曲げモードを図10に示す。この平板を対象に ねじりモードの固有振動数を目標值（ここでは例とし て $130 \mathrm{~Hz})$ にする以下の設計問題を考える.

目的関数 : ねじりモードの固有振動数の計算値と目 標值 $(130 \mathrm{~Hz})$ の差を最小

設計変数 : 平板の幅 $(w)$

制約条件： $110 \leqq w \leqq 180 \mathrm{~mm}$

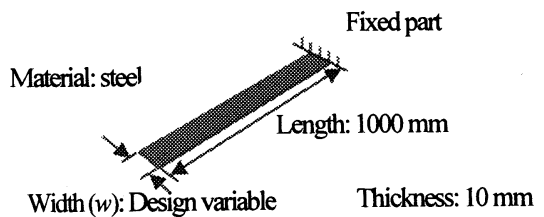

Fig. 9 Cantilever plate
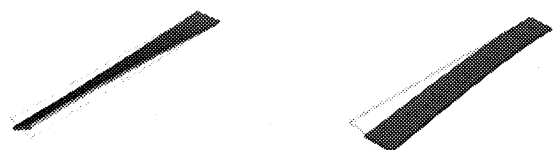

(a) Torsion mode $(99.2 \mathrm{~Hz})$ (b) Inplane bending mode $(134.0 \mathrm{~Hz})$

Fig. 10 Natural frequency and natural vibration mode at width $165 \mathrm{~mm}$

(2) 計算結果計算結果を図11に示す. 固有振動 モードトラッキング機能を用いていない場合は, ねじ りモードの固有振動数は, $115.1 \mathrm{~Hz} ゙$ あり目標の $130 \mathrm{~Hz}$ とはならない. しかし, 固有振動モードトラッキング 機能を用いた場合は, 㸚じりモードの固有振動数の計 算値は $130.0 \mathrm{~Hz}$ となる.

固有振動モードトラッキング機能を備えていない場 合は, 同じ次数の固有振動モードの固有振動数を読み 込む. そのため, 初期值 (図中の $\triangle$ ) からスタートし, はじめはねじりモードを追跡するが，モードスイッチ ングが起きると, 今度は面内の曲げモードを追跡して しまう. そして目標值に最も近い固有振動数の值とそ のときの板幅140.8 mm（図中の口）を最適解として探 索する. 一方, 開発した機能を付加すると, 図12に示
すように，ねじりモードと面内曲げモードを異なるパ ターンとして明確に判別し, 固有振動モードを追跡で きる.このため，モードスイッチングが起きても見失 わず，ねじりモードの固有振動数が目標值となる板幅 $123.8 \mathrm{~mm}$ (図中の○) を探索することができる.

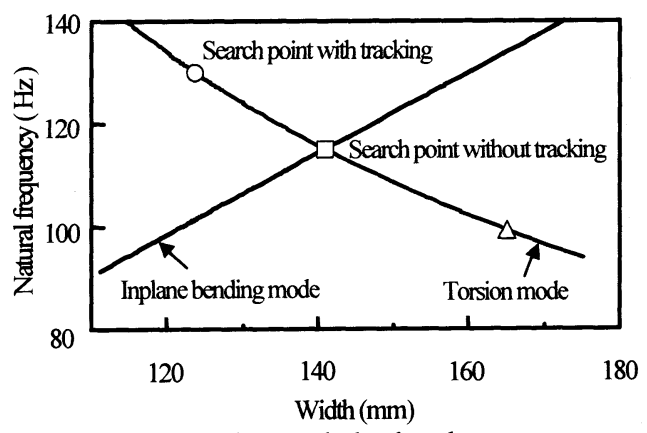

Fig. 11 Calculated results

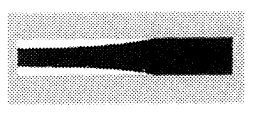

$W: 2 \quad B: 1$

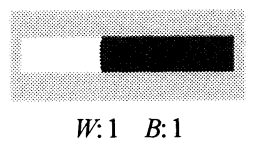

$\begin{array}{ll}\text { (a) Torsion mode } & \text { (b) Inplane bending mode }\end{array}$

Fig. 12 Binary images of natural vibration mode

\section{$4 \cdot 2$ リブが付加された片持ち平板}

(1) 計算モデル 実際の構造物の設計で生じる, リブなどの新たな部材を着脱するようなメッシュの再 分割を必要とする大幅な形状変更が行われる問題に対 する開発機能の有効性を確認する.

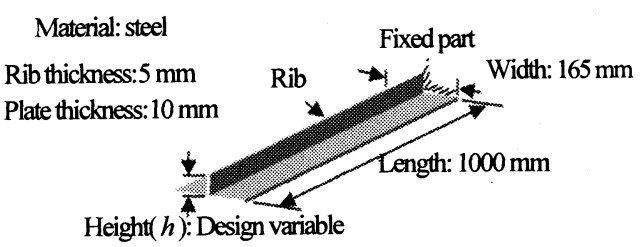

Fig. 13 Cantilever plate with new reinforced rib

図13に示すように, ここでは前節で用いたものと同 一の一端が固定された平板の中央に, 新たな部材とし てリブを追加する.この平板を対象に曲げ2次モード の固有振動数を, 初期值 $52.4 \mathrm{~Hz}$ から目標值（ここでは 例として $120 \mathrm{~Hz})$ にする設計問題を考える.

目的関数 : 曲げ2次モードの固有振動数の計算值と 目標値 $(120 \mathrm{~Hz})$ の差を最小

設計変数 : リブの高さ $(h)$

制約条件： $0 \leqq h \leqq 50 \mathrm{~mm}$ 
(2) 計算結果計算結果を図14に示す. 初期値 (図中の $\triangle$ ) のリブの高さ0 mmからスタートし, 最 適解（図中の○）として, 曲げ2次モードの固有振動 数の計算值が $120.0 \mathrm{~Hz}$ となるリブの高さ $30.7 \mathrm{~mm}$ を探索 している. 図14からわかるように設計変数（リブ高 さ）の值によってモードスイッチングが生じているが, 本手法を用いれば，図15に示すように固有振動モード を画像のパターンとして明確に判別することが可能と なる. そのため, モードスイッチングが生じる場合で も固有振動モードを追跡することが可能となる．新た な部材を追加する大幅な形状変更が生じるモードスイ ッチング問題に対しても, 目的関数を満たす設計変数 を探索できることを確認した.

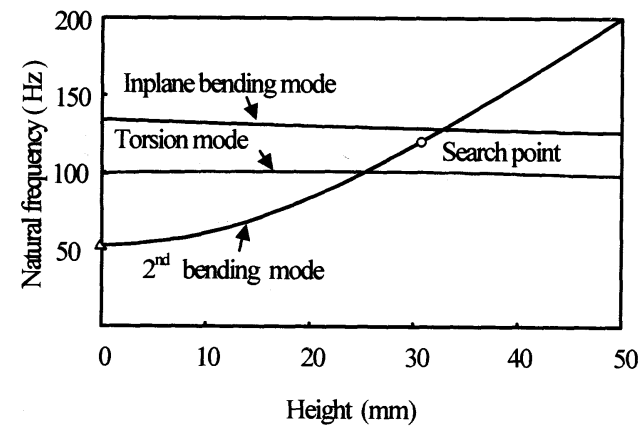

Fig. 14 Calculated results

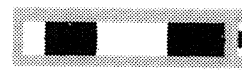

$W: 2 \quad B: 2$

$W: 2 \quad B: 1$

$W: 1 \quad B: 1$

(a) $2^{\text {nd }}$ bending mode

(b) Torsion mode

(c) Inplane bending mode
合，はじめに問題とするのは局所的な振動ではなく大 域的な振動なので, 固有振動モードを判別できる範囲 で可能な限り容易であることが望ましいと考え，2值 化した画像の白あるいは黒の集合数の一致度合いで判 別する方法をとっている. しかし，2值化した場合， 位相情報, すなわち変形の方向は考慮されないので, 高次モードまで対象を広げていく上で，今後の課題と 考えている.

また実際の設計では，内部にある構造物，あるいは 形状によっては見えない部分の振動を問題にする場合 もある. しかしこのような場合でも，プリプロセッサ で注目する部分を指定して表示することにより，本ア ルゴリズムを適用することが可能であると考える.

\section{5. 結論}

実際の構造物の振動設計で必要となる新たな部材の 着脱等の大幅な形状変更にも対応可能な，画像演算に よる固有振動モードトラッキングの新しいアルゴリズ ムを考案した. 本アルゴリズムの特徴は, ポストプロ セッサが出力した固有振動モードベクトルの各成分の 絶対値を色の濃淡で表示した濃淡図を作成し，これを 2 值化処理した後, 2 值画像で連続して同一色となる 領域を一つの集合と数え, その集合の数によって追跡 する固有振動モードを判別する点である．まず，片持 ち平板を対象に板幅を変更し，アルゴリズムの有効性 を確認した．また，新たな部材としてこれにリブを追 加し, メッシュの再分割を必要とする大幅な形状変更 に対しても，本アルゴリズムが有効であることを確認 した.

Fig. 15 Binary images of natural vibration mode

尚,ここではメッシュの再分割を必要とする大幅な 形状変更に対するアルゴリズムの有効性を示すため, 平板に新たにリブを追加したモデルを用いた．これは 片持ち平板の板幅を変えるような場合, メッシュを伸 縮する等, メッシュの再分割を必要としない方法もと り得るためである.ただしここではそのような方法は 用いていないので， $4 \cdot 1$ 節の計算においてもメッシュ の再分割を行っている.

本アルゴリズムでは2值化した画像を用いて固有振 動モードの判別を行っているが，階調を増やすことに より, 固有振動モードをより正確に表せる可能性があ る. しかし階調を増やした場合は画像のパターン情報 が増えるため, 追跡する固有振動モードを判別するア ルゴリズムも複雑になる. しかし振動設計で多くの場

\section{文献}

(1) Ewins, D. J., Modal Testing: Theory and Practice, (1986), Brüel \& kjær.

(2) Ting T. et al., Automated Mode Tracking Strategy, ALAA, Journal, Vol. 33, No. 1 (1995), pp. 183-185.

(3) Eldred, M. S. et al., Mode Tracking Issues in Structural Optimization, ALAA, Journal, Vol. 33, No.10 (1995), pp. 19261933.

(4) Bahra, A. S. and Greening, P. D., Mode Traces in Degenerate Eigensystems and Augmented Assurance, ALAA, Journal, Vol. 43, No. 6(2005), pp.1299-1305.

(5) Ma, Z.-D. et al., Development of Structural Optimization Method for Vibration Reduction (1st Report, Structural Optimization Theory Using the Homogenization Method), Transactions of the Japan Society of Mechanical Engineers, Series C, Vol. 59, No. 562 (1993), pp. 1730-1736.

(6) Kim, T. S. and Kim, Y. Y., Mac-based Mode-tracking in Structural Topology Optimization, Computers and Structures, Vol. 74, (2000), pp. 375-383. 